\title{
Barriers to longitudinal river connectivity: review of impacts, study methods and management for Iberian fish conservation
}

\author{
Amaia A. Rodeles*, David Galicia and Rafael Miranda \\ Department of Environmental Biology, University of Navarra C/ Irunlarrea 1, 31008 Pamplona (Spain). \\ * Corresponding author: aangulo@alumni.unav.es
}

Received: 05/07/19 Accepted: 10/09/19

\begin{abstract}
Barriers to longitudinal river connectivity: review of impacts, study methods and management for Iberian fish conservation
\end{abstract}

River connectivity is essential for the correct functioning of freshwater ecosystems at all scales. However, it has not received the necessary attention by researchers, managers and policymakers until recent years. In this review, we recap the state of knowledge in river connectivity and its applications to conservation. We describe the particular characteristics of river connectivity and summarise the effects of its interruption in different freshwater ecosystem elements. We then focus on the effects of the lack of segment connectivity in fish species and review the different methods developed to study it. The application of connectivity in freshwater fish conservation areas is also reviewed, which highlights the lack of studies on this subject. Finally, connectivity restoration is studied. The review addresses these topics in a general way and then focus on the Iberian Peninsula. The Iberian Peninsula is an interesting place to study river connectivity because it has one of the highest numbers of dams per square kilometre and a large number of endemic and endangered freshwater fish species. Despite the high number of fish species affected by water extraction and damming, river connectivity and its effect in Iberian freshwater fish populations have not been well studied. A small number of studies analyse the effect of small dams in nearby fish communities, but large-scale impact assessments are scarce. More connectivity analyses are needed to improve freshwater ecosystem conservation strategies. We conclude addressing some gaps in the knowledge of fragmentation and research opportunities in river connectivity and conservation

Key words: connectivity indices, dam removal, Iberian Peninsula, population isolation, river connectivity, river conservation

\section{RESUMEN}

Barreras para la conectividad fluvial longitudinal: revisión de impactos, métodos de estudio y gestión para la conservación de los peces ibéricos

La conectividad de los ríos es esencial para asegurar el correcto funcionamiento de los ecosistemas fluviales a todas las escalas. Sin embargo, no ha recibido la atención necesaria por parte de los investigadores, los gestores y los politicos hasta hace pocos años. En esta revisión recapitulamos el estado del conocimiento de la conectividad fluvial y sus aplicaciones en conservación. Describimos las particularidades de la conectividad de los ríos y resumimos los efectos causados por la fragmentación en diferentes elementos de los ecosistemas fluviales. Después nos centramos en los efectos que la falta de conectividad tiene en las especies de peces y revisamos los distintos métodos desarrollados para estudiar la fragmentación. También exploramos la aplicación de los estudios de conectividad en la selección de áreas para la conservación de ríos. Por último se estudia la restauración de la conectividad fluvial. La revisión analiza estos temas de una forma general para luego centrarse en la península Ibérica. La península Ibérica es un lugar interesante para estudiar la conectividad fluvial ya que contiene uno de los mayores números de presas por kilómetro cuadrado y una gran cantidad de especies de peces dulceacuícolas endémicas y amenazadas. A pesar del gran número de especies de peces amenazadas por la extracción de agua y las presas, la fragmentación fluvial y sus efectos no han sido bien estudiados. Encontramos que se ha realizado un pequeño número de estudios sobre los efectos de presas pequeñas a escala local, pero los análisis a gran escala son escasos. Se necesitan más estudios de conectividad de ríos para mejorar las estrategias de conservación de los ecosistemas fluviales. Concluimos la revisión mostrando algunos huecos en el conocimiento de la fragmentación de ríos y comentando nuevas 
oportunidades de investigación en el estudio de la conectividad fluvial y su restauración.

Palabras clave: aislamiento de poblaciones, conectividad fluvial, conservación de ríos, derribo de presas, índices de conectividad, península Ibérica

\section{WHAT IS HYDROLOGICAL CONNEC- TIVITY?}

Connectivity can be defined as the degree to which a landscape facilitates or impedes the movement of organisms among resource patches (Taylor et al., 1993). Landscape connectivity is a fundamental factor in determining the distribution of species and is an essential concept in meta-population biology and landscape ecology (Pringle, 2003).

Although connectivity has been addressed in numerous land studies, hydrological connectivity presents some challenges derived from the peculiar structure of rivers (Fausch et al., 2002; Wiens, 2002). River ecosystems are hierarchically organised dendritic networks, with functional habitats nested across scales. This structure creates isolated populations at smaller spatial scales than in other ecosystems (Fagan, 2002; Campbell Grant et al., 2007; Crook et al., 2015). Movement of organisms inside the river is constrained to following the network branches, and a single barrier can divide a river segment into two totally isolated fragments (Campbell Grant et al., 2007). Moreover, the flow of water is unidirectional, running from the headwaters to the river mouth, transporting sediments, nutrients and organisms. This means that despite the lack of spatial overlap, downstream ecosystems are affected by processes occurring upstream: the flow of water controls hydrologic connectivity (Fullerton et al., 2010).

Hydrological connectivity can be defined as the water-mediated transfer of matter, energy or organisms within or between elements of the hydrologic cycle (Pringle, 2001). Hydrological connectivity is composed of interactive pathways along one temporal and three spatial dimensions: longitudinal (from headwaters to river mouth), lateral (from riverine and riparian habitats to floodplains) and vertical (from riverine to groundwater, Pringle, 2001). There are also two types of connectivity (Branco et al., 2014): structural connectivity refers to the physical relationships between structural elements (Segurado et al., 2013), while functional connectivity is defined as the response of the biological elements (community, populations) to landscape structure (Tischendorf \& Fahrig, 2000).

Hydrological connectivity is essential to the ecological integrity of freshwater ecosystems, and reduction or enhancement of this property can have major negative environmental effects (Moss, 2000; Pringle, 2003; Kondolf et al., 2014; Grill et al., 2015; Schmutz \& Moog, 2018; Seliger \& Zeiringer, 2018). However, until recently, freshwater connectivity and conservation have not received the attention they deserve from scientists and administrators. Less than 20 $\%$ of papers published on three important conservation journals between 2011 and 2015 focused on freshwater ecosystems (Di Marco et al., 2017), while only $9 \%$ of connectivity studies applied to conservation between 2000 and 2013 studied fluvial ecosystems (Correa Ayram et al., 2015). Moreover, the research is highly skewed towards developed countries, mainly the United States, and diadromous species such as salmonids (Stanley et al., 2007; Bourne et al., 2011; Keefer et al., 2012; Brown et al., 2013).

In this review we will focus on the Iberian Peninsula. The Iberian Peninsula is a very interesting place to study hydrologic connectivity for two reasons: first, it has one of the highest percentages $(>70 \%)$ of endemic freshwater fish species in Europe (Clavero et al., 2004; Reyjol et al., 2007; Maceda-Veiga, 2013). Second, Spain is one of the countries with the highest dam density per square kilometre in the world (Vidal-Abarca Gutiérrez \& Suárez Alonso, 2013), while Portugal also has a large number of dams (Antunes et al., 2016; Fig. 1). According to some estimations there are at least 26000 river obstacles in Spain 


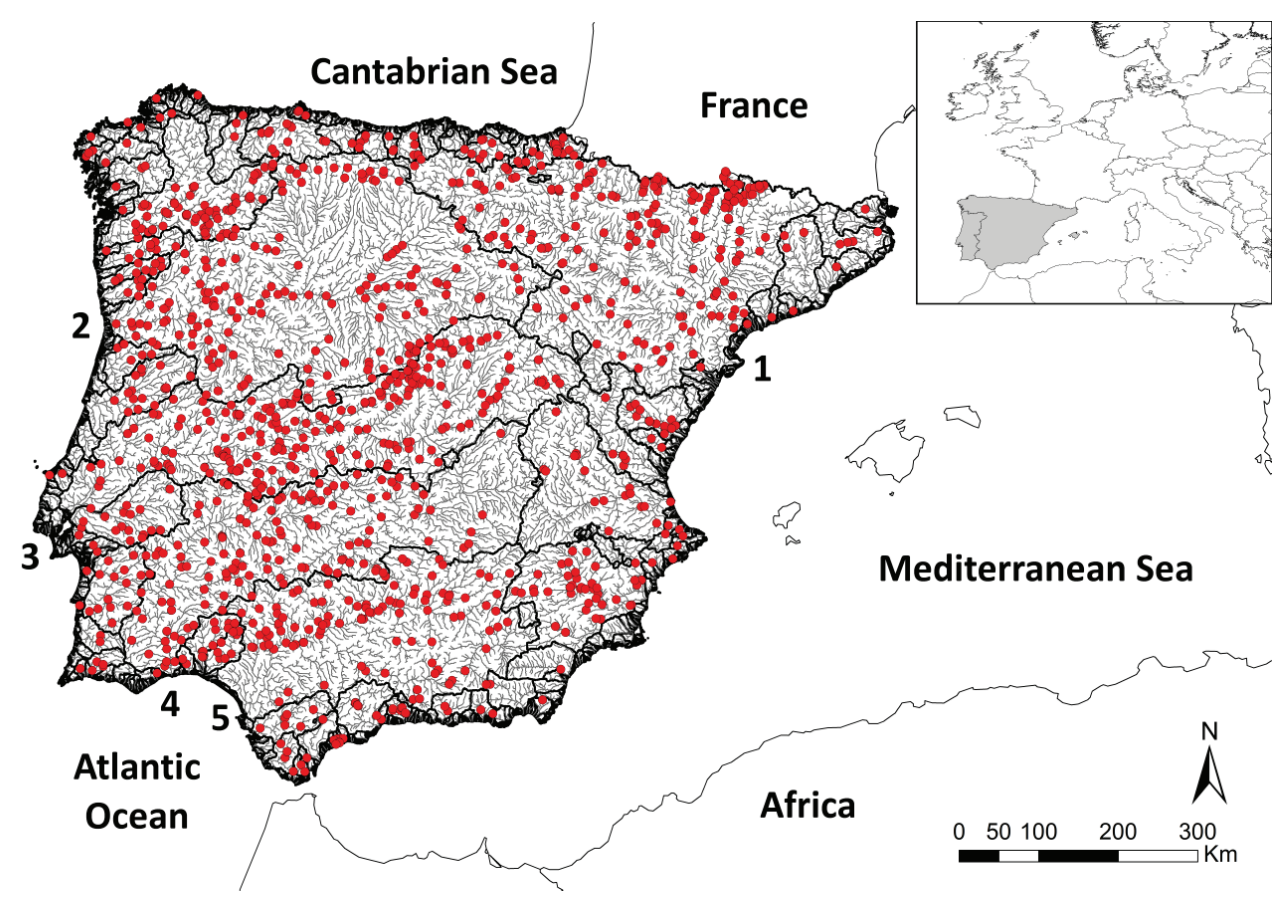

Figure 1. The Iberian Peninsula, its river basins and large dams $\left(>1 \mathrm{hm}^{3}\right)$. Numbers point to the main Iberian river basins by area. 1: Ebro River basin, 2: Duero River basin, 3: Tagus River basin, 4: Guadiana River basin, 5: Guadalquivir River basin. La península Ibérica, sus cuencas fluviales y sus grandes presas $\left(>1 \mathrm{hm}^{3}\right)$. Los números marcan las principales cuencas de acuerdo con su área. 1: río Ebro, 2: río Duero, 3: río Tajo, 4: río Guadiana, 5: río Guadiana.

alone (Rincón Sanz \& Gortázar Rubial, 2016).

The larger river basins of the Iberian Peninsula are Ebro, Duero, Tagus, Guadiana and Guadalquivir. These basins are heavily fragmented. For example, the Spanish Duero basin $\left(78900 \mathrm{~km}^{2}\right)$ has 145 large- and medium-sized dams (22 in the main stem) and more than 3200 small dams and weirs (Confederación Hidrográfica del Duero, 2007). The total river length of the basin is 13539 $\mathrm{km}$, so, on average, there is a barrier every $4 \mathrm{~km}$. The Ebro basin $\left(85000 \mathrm{~km}^{2}\right)$ has 299 large dams and 1818 weirs and small dams (Confederación Hidrográfica del Ebro, 2009) in $12495 \mathrm{~km}$ of rivers and an average of one dam per $6 \mathrm{~km}$. This has profound effects in river ecosystems.

In this review, we will summarize in four sections the state of the knowledge of i) the effects of river fragmentation in freshwater fishes, ii) the methods developed to calculate connectivity, iii) the studies of river conservation and iv) the studies about dam removal and connectivity restoration. Each section will start with a general study and then they will focus on river fragmentation studies on the Iberian Peninsula. Finally, we will comment on understudied areas and research opportunities in freshwater connectivity conservation and management. Longitudinal connectivity (i.e. connectivity along river course) is the most studied form of connectivity, so this review will focus on the effects of the disruption of this dimension of hydrological connectivity (structural and functional) in fish species.

\section{IMPACTS OF LONGITUDINAL CONNEC- TIVITY FRAGMENTATION IN FRESH- WATER FISHES}

Large dams, weirs and culverts are the main infrastructures causing river connectivity fragmentation, but their effects on freshwater ecosystems depend on network location, number, passability (i.e. degree of permeation of a barrier measured with different methods), etc. With more than 45 000 large dams and countless small obstacles 
worldwide, river fragmentation is one of the most important threats facing river ecosystems (Gido et al., 2016; Kemp, 2016). Currently, nearly $50 \%$ of the freshwater ecoregions of the world and $48 \%$ of global river volume are affected by large- and medium-sized dams (Liermann et al., 2012; Grill et al., 2015).

As barriers interrupt the natural downstream flow of matter and energy, they cause numerous different impacts in freshwater fishes, derived from altered hydrological and sediment regimes (Bunn \& Arthington, 2002; Kondolf et al., 2014). In addition, the mere loss of connectivity between two adjacent segments could have negative effects on freshwater organisms, especially fishes (Gido et al., 2016). The impossibility of movement through a barrier can affect breeding and feeding migrations and recolonization processes, leading to biodiversity losses. Analysing the effects of one or multiple obstacles on fish species or communities may often be a difficult task due to the masking influence of natural environmental variability or other local and regional impacts (Cumming, 2004; Wang et al., 2011; Gido et al., 2016).

Fishes with different life cycles react differently to the loss of connectivity. Fragmentation of a river basin is more concerning for diadromous fish populations. Diadromous species are the ones that move between the rivers and the ocean to complete their life cycles. The effect of an impassable dam on these species is obvious: the obstacle obstructs the migration of fishes, resulting in the loss of the whole habitat upstream of the barrier. If habitat loss is great enough, the diadromous population affected will decline or even disappear from the river basin (Duncan \& Lockwood, 2001; Sheer \& Steel, 2006; Fukushima et al., 2007; Limburg \& Waldman, 2009; Lucas et al., 2009; Hitt et al., 2012; Nieland et al., 2015; Segurado et al., 2015). Even if the obstacles are partially passable, negative effects remain as migrant fauna spend more time and energy trying to pass the barriers, which leads to lower spawning success, physical damage, easier capture and disease spread (Gregory et al., 2002; March et al., 2003; Garcia de Leaniz, 2008).

The effect of dams in potamodromous species (i.e. fishes constricted to freshwater water that conduct migrations of different spatial scale along the rivers) is more obscure, as they lose migration paths, but stream segments usually have all types of habitat needed by these fishes. Some potamodromous fish species also perform large migrations to spawn, which are affected by dam presence (Lucas \& Batley, 1996; Branco et al., 2017).

Fish species are structured in meta-populations (Fagan, 2002; Gido et al., 2016). A meta-population comprises different populations distributed over patches on a heterogeneous landscape connected by dispersal movements. In meta-population theory, local extinctions are offset by recolonizations from other patches, and population genetics depends on the genetic characteristics of the colonizers (Levins, 1968; Hanski \& Gilpin, 1991).

In hierarchical dendritic linear systems, such as rivers, there is only one path between sites, and dispersers must pass through all middle points before reaching a destination (Fagan, 2002). When a dam or other barrier is constructed, a path between populations can be completely blocked to dispersers, which can lead to loss of genetic diversity, genetic drift, population decline and eventually, extirpation of the isolated population (Morita \& Yamamoto, 2002; Meldgaard et al., 2003; Yamamoto et al., 2004; Wofford et al., 2005; Morita et al., 2009). These effects can be magnified if populations are isolated in smaller areas (MacArthur \& Wilson, 1967)

Different studies have shown a positive connection between larger river segments and higher freshwater fish biodiversity (Bain \& Wine, 2010; Heino et al., 2015) and a negative relationship between dam presence and species richness upstream (Dodd et al., 2003; Nislow et al., 2011; Wang et al., 2011; Perkin \& Gido, 2012; Sá-Oliveira et al., 2015). Other studies do not show differences in fish communities between segments separated by dams (Cumming, 2004; Santos et al., 2006). However, even if population changes have not been noticed yet, species extirpation from an isolated river segment cannot be ruled out as there may be delayed long-term effects (Ewers \& Didham, 2006). This is called "extinction debt" and arises from delayed responses of populations to an impact (for exam- 
ple, when mortality slightly exceeds natality). In any case, river network connectivity is one of the main drivers in the distribution and range size of freshwater fish species (Carvajal-Quintero et al., 2019) so river fragmentation has direct consequences on the distribution and persistence of freshwater fish species, according to the degree of connectivity between populations and the size of the habitats affected.

In the Iberian Peninsula, the profound degradation of hydrologic connectivity described in the above has led to the extinction or dramatic decline of migrant fish species (Atlantic sturgeon Acipenser sturio L., 1758, Atlantic salmon Salmo salar L., 1758, European eel Anguilla anguilla (L., 1758), etc.), the isolation of endemic species and the spread of exotic species (Prenda et al., 2006). However, studies of dam impacts and river connectivity loss in fishes are insignificant, despite affecting up to $60 \%$ of Iberian freshwater fish species (Maceda-Veiga, 2013). Atlantic salmon has lost up to $86 \%$ of its historically accessible stream length (Álvarez et al., 2003), completely disappearing from the Duero River basin (Valente \& Maia, 2001) and decreasing dramatically in the Cantabrian coast (Álvarez et al., 2001; Sanz Azcárate et al., 2018). Sturgeon was completely extirpated from Iberian river basins (Morais, 2008), the European eel has lost more than $80 \%$ of its historic distribution range (Clavero \& Hermoso, 2015), and other migrant species such as the sea lamprey (Petromyzon marinus L., 1758) are declining (Nicola et al., 1996).

The majority of endemic Iberian fish species are economically unimportant potamodromous fishes, and the effects of dams in their populations are unknown. The scarcity of information on the biology and conservation status of these species and the absence of river fragmentation studies make it difficult to start adequate conservation and management plans. Due to the strong speciation in the different river basins, fish species are naturally strongly isolated, and some of them only appear in single river basins or sub-basins, which makes them even more vulnerable to additional connectivity alterations and habitat degradation (Aparicio et al., 2000; Clavero et al., 2010).
Studies of dam impacts were conducted in different river basins scattered throughout the territory. A study on the Tagus basin showed that recruitment of brown trout (Salmo trutta L., 1758) after the construction of a hydropower dam decreased significantly, showing that dams, even small ones, have effects downstream (Almodóvar \& Nicola, 1997). Dams also promote exotic fish invasion and fish community homogenization along the Guadiana River (Clavero \& Hermoso, 2011). Cold water discharge from a newly constructed dam caused a shift from a mixed fish community to a salmonid one (Miranda et al., 2012). Another study in Catalonia (north-east of the Iberian Peninsula) indicates that fish extinctions are more likely in small, degraded and regulated stream segments (Aparicio et al., 2000). Impacted stretches on Catalan basins also seem to have poorer habitat structure, lower fish abundance, fish length and total fish weight, and different species composition, with an effect that accumulates downstream (Benejam et al., 2014). Conversely, other studies did not find significant effects of small barriers on fish communities in Spain (Alexandre \& Almeida, 2010) or Portugal (Santos et al., 2006).

\section{METHODS TO STUDY LONGITUDINAL RIVER CONNECTIVITY}

As hydrological connectivity has received growing attention in the last two decades (Pringle, 2001, 2003; Wiens, 2002), different methods have been developed to assess connectivity and the best solutions to improve it.

To analyse river connectivity, obstacle passability must be assessed first. Passability may be defined as the proportion of fish that are able to pass a barrier or the number of days the barrier is passable. Due to the unique characteristics of each barrier and river reach, assessing passability is usually a difficult task. The simplest methods use a binary passability value $(0-1)$ : a barrier is passable or not (Zheng et al., 2009). In numerous cases, barriers are partially passable depending on different factors, such as obstacle height, species, size, swimming ability and flow of water (Kemp \& O'Hanley, 2010). There are multiple ways to assess passability, from expert criteria (Kemp \& 
O'Hanley, 2010) and telemetry and fish surveys (Ovidio \& Philippart, 2002) to software simulations such as FishXing (Bourne et al., 2011) and statistical models (Kemp \& O'Hanley, 2010).

With the passability values of the obstacles, different indices can be applied to determine the connectivity of a stream or river basin, taking into account the position of each dam in the network. The simplest ones are score-and-ranking type procedures, which rank obstacles according to their passability, but they produce ineffective solutions to improve connectivity as they assess the passability of individual barriers and ignore their cumulative impacts (O'Hanley \& Tomberlin, 2005).

Recently, graph theory, a method frequently used in landscape functional connectivity (Pascual-Hortal \& Saura, 2006; Galpern et al., 2011), has been adapted to river networks in different connectivity studies (Fullerton et al., 2011). Graph networks commonly represent freshwater systems as edges (river segments) connected by nodes (intersections or barriers). By including obstacle location inside the river network in the analysis, graph theory allows the calculation of cumulative impacts of dams, providing an efficient way to estimate the different sections affected by obstacles (Erös et al., 2011; McKay et al., 2013; Branco et al., 2014; Rincón et al., 2017). Graph theory has not been widely used, but it is gaining more attention and could be used for numerous analyses, such as species connectivity, habitat loss and gain models (Segurado et al., 2015), dam removal selection (McKay et al., 2013; Branco et al., 2014) or colonization and extinction-risk models (Van Looy et al., 2013). Other indices also use dam location inside the river network to analyse cumulative impacts on longitudinal connectivity (Cote et al., 2009; Grill et al., 2014). Some indices are developed to analyse diadromous fish movements, as they migrate from the river mouth upstream (Cote et al., 2009; McKay et al., 2013), while others are used to assess potamodromous movements inside the river (Cote et al., 2009; O'Hanley et al., 2013; Diebel et al., 2015).

In general, connectivity indices use segment length or water volume as a measure of river habitat availability (Cote et al., 2009; McKay et al., 2013; Branco et al., 2014; Grill et al., 2015). However, other segment habitat characteristics may reflect biota needs better than length or water volume: a small segment of high-quality habitat (according to the species requirements) could be more beneficial than a larger segment of poor quality habitat. Different connectivity indices include both river length and habitat quality for both a large variety of fish species (Grill et al., 2014; Diebel et al., 2015; Maitland et al., 2016) or a single species (Rodeles et al., 2019) to adapt their results to fish habitat requirements.

The result of these indices is usually a percentage that represents the connectivity for one obstacle or for the whole river basin (Cote et al., 2009; Kemp \& O’Hanley, 2010; McKay et al., 2013).

Connectivity evaluation methods are often used to model potential connectivity improvements (Branco et al., 2014). For example, dam removal is a useful tool to improve river connectivity, but if it is not carefully planned, restoration benefits would be suboptimal (Rodeles et al., 2017). Optimization tools that rank dams by their effects on network connectivity and their removal cost have been developed to maximize river connectivity improvements. O'Hanley \& Tomberlin (2005) developed a optimization method using integer programming techniques that produced better results than scoring and ranking procedures, and applied it in Washington State (USA). Afterwards, the optimization method was refined and updated with different techniques (mixed integer linear programming, probability chains, etc.) to include different fish species and spatial scales (O'Hanley \& Tomberlin, 2005; O'Hanley, 2011; O'Hanley et al., 2013; Null et al., 2014; King \& O'Hanley, 2016; King et al., 2017). Null et al. (2014) used another optimization method to analyse trade-offs between hydropower generation, water supply and river connectivity in California (USA). The same tools described above can be used to choose the locations for new dams, analysing the river network to select the least impacting sites for river basin connectivity. However, as far as we know, these studies do not exist yet. For a deep review on the methods selected for connectivity 
barrier prioritization, read McKay et al. (2017).

River connectivity studies in Spain are scarce, although some research has been performed in Catalan basins regarding fishway efficiency and dam passability (Ordeix et al., 2011; Solà et al., 2011; Aparicio et al., 2012). A new connectivity index with asymmetric dam passability was developed and applied to a sub-basin of the Duero River basin (Rincón et al., 2017). In Portugal, longitudinal river connectivity indices have been developed to aid in river connectivity restoration (Branco et al., 2012, 2014; Segurado et al., 2013, 2015). However, major river basin connectivity assessments have not been performed yet. Numerous small dams and weirs in different river basins are not inventoried, which prevents comprehensive longitudinal connectivity analyses (Rincón Sanz \& Gortázar Rubial, 2016; Rodeles et al., 2017). We need to know the full extent of Iberian river fragmentation to understand the degree of the threat faced by our freshwater fish species. It will also serve as the starting point for river connectivity restoration, helping to make informed decisions on dam removal.

\section{LONGITUDINAL CONNECTIVITY AND RIVER CONSERVATION}

Conservation actions have generally been unsuccessful in the case of freshwater biodiversity due to the special characteristics of freshwater ecosystems and the lack of attention they receive (Dudgeon et al., 2006), with very few studies focusing on fluvial systems (Correa Ayram et al., 2015).

Reserves have been a popular conservation technique for terrestrial ecosystems around the world (Geldmann et al., 2013). Nevertheless, there are few specifically freshwater protected areas (Bower et al., 2015); river segments are protected tangentially by being part of a protected land ecosystem, which does not guarantee effective protection (Saunders et al., 2002; Hermoso et al., 2015; Miranda \& Pino-Del-Carpio, 2016).

Numerous studies exist about the selection of terrestrial areas for conservation and the importance of landscape connectivity to reserves (Correa Ayram et al., 2015). However, river structure makes it impossible to extrapolate terrestrial conservation techniques to freshwater ecosys- tems (Moilanen et al., 2008; Hermoso et al., 2015). The selection of isolated river stretches for protection is not as useful as the selection of land ecosystems because rivers are affected by the upstream and downstream drainage network, the riparian zones and the surrounding land (Pringle, 2001; Bower et al., 2015; Hermoso et al., 2015). River connectivity is essential for the well-being of freshwater ecosystems, and recently, some studies have included river connectivity as a variable in the selection of freshwater reserves (Hermoso et al., 2012, 2017). However, the exclusive conservation of freshwater ecosystems and the design of protected areas have received little effort, and only a small fraction of scientific papers are about freshwater connectivity and its application to fluvial conservation (Galpern et al., 2011; Hermoso et al., 2011, 2017; Correa Ayram et al., 2015; Erös et al., 2018).

Adequate methods are needed for the selection of conservation areas, but because freshwater ecosystems have been less studied, there are no specific tools for the scientific selection of reserves. Software used in terrestrial ecosystems, such as ZONATION and Marxan, is being adapted for the design of river reserves (Moilanen et al., 2008; Hermoso et al., 2011; Hermoso et al., 2017), as well as methods for the analysis of connectivity, such as graph theory (Erös et al., 2011; Fullerton et al., 2011).

Ideally, a freshwater protected area should cover the total length of a river to ensure the adequate conservation of all ecosystems. Rivers are heavily exploited along their courses and may cross different countries in their travel to the oceans, so this approach would find the resistance of governments; therefore, partial solutions are being proposed (Saunders et al., 2002). River connectivity needs to play an essential role in the selection of river reserves as it will determine their conservation efficacies (Hermoso et al., 2015, 2017).

To ensure the conservation of near pristine, non-impacted river stretches, Spain declared 135 Freshwater Natural Reserves (FNR) scattered throughout the country (Fig. 2). The first 82 FNRs were registered in 2015, followed by another batch of 53 reserves in 2017 (Ministerio para la Transición Ecológica, 2017). These 
FNRs are a first and very important step in the conservation of freshwater ecosystems in the Iberian Peninsula. However, these reserves do not consider river connectivity between them or even within them, with some FNRs fragmented by dozens of small obstacles (Fig. 3). Due to this, the FNRs are not very efficient for the conservation of fish populations. A connected network of freshwater reserves needs to be protected to achieve effective conservation of river fauna.

Moreover, Iberian Peninsula freshwater ecosystems face new threats, such as climate change, that will further disturb hydrological regimes and imperil fish species (Smith \& Darwall, 2006; Hermoso \& Clavero, 2011; Schewe et al., 2014). Iberian countries need to seriously engage in plans to protect the water supply while preserving freshwater ecosystems and their connectivity with cohesive national plans and sensible management that allows for conservation. In this way, Spain and Portugal will effectively protect their freshwater resources and species.

\section{EFFECTS OF LONGITUDINAL CONNEC- TIVITY RESTORATION}

Although dam impacts on freshwater fish species are fairly well studied, upstream and downstream dam removal effects are far less analysed (Bednarek, 2001; Hart et al., 2002). The lack of pre- and post-dam removal ecological monitoring is the main reason for the scarcity of dam removal studies (Bednarek, 2001; Doyle et al., 2003, 2005; Rodeles et al., 2017). Dam removal is performed under the assumption that its effects will be positive, but long-term studies ( $>5$ years) on this topic are usually not found. Long-term monitoring is needed because ecological feedback loops may operate on longer time spans (Bellmore et al., 2019), and some studies suggest that 3-4 years after dam removal, the biota is still in transition (Maloney et al., 2008; Poulos et al., 2014).

Numerous short-term studies show positive effects, such as upstream recolonization and population increase of diadromous fish species (Fjeldstad et al., 2012; Hitt et al., 2012; Pess et al., 2014; Lasne et al., 2015; Birnie-Gauvin et al.,

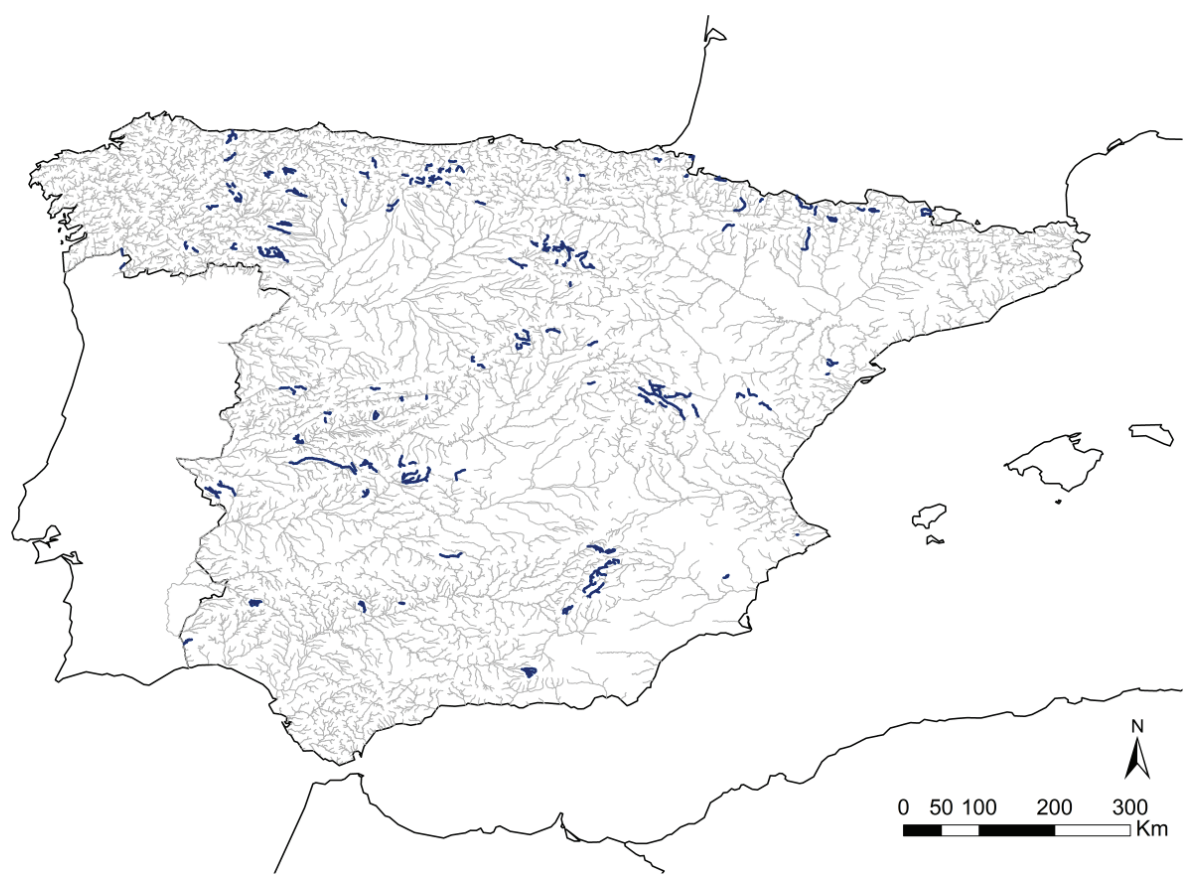

Figure 2. Location of the 135 Freshwater Natural Reserves created in Spain. They are mainly small headwater streams. Localización de las 135 Reservas Naturales Fluviales creadas en España. La mayoría son pequeños ríos de cabecera. 


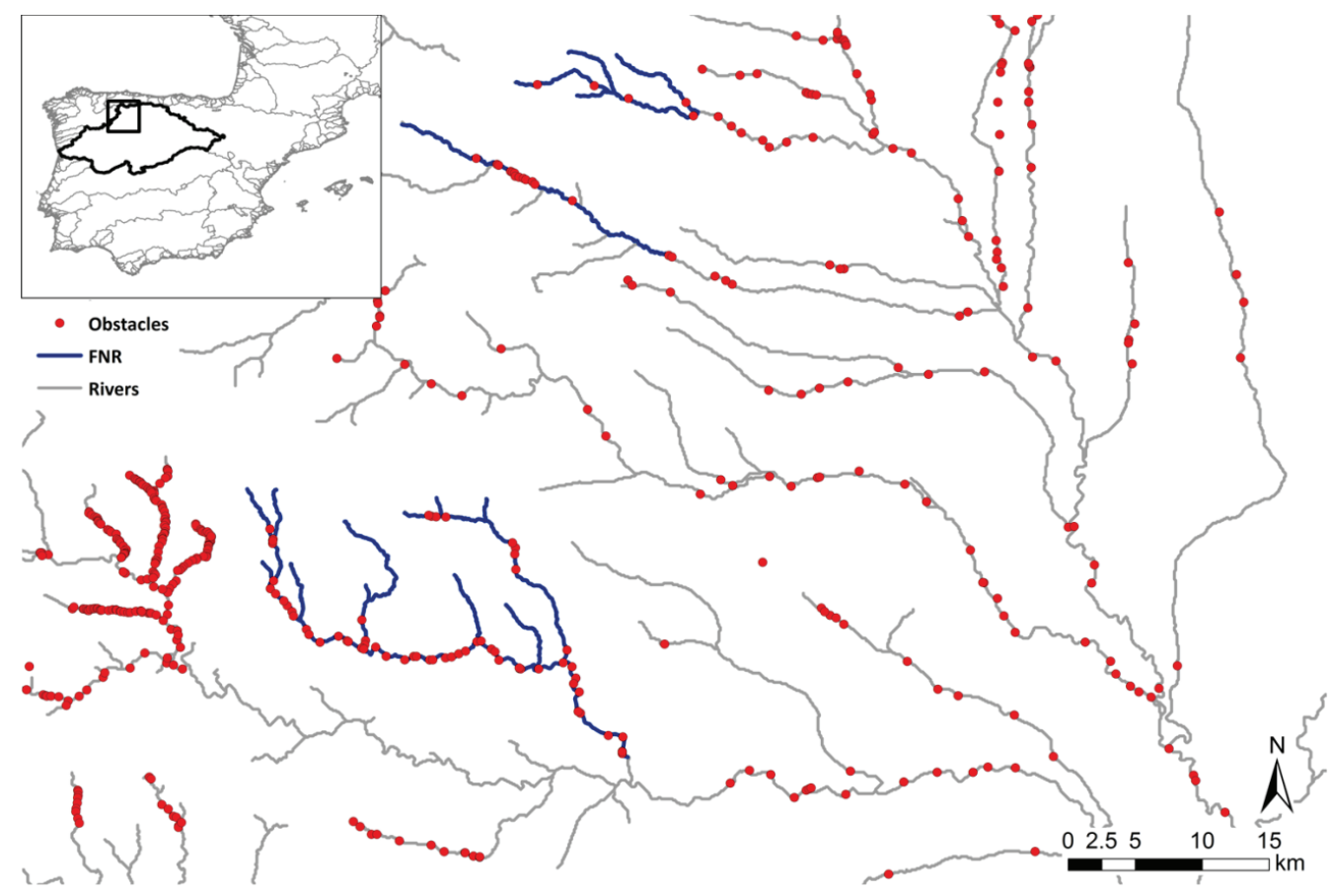

Figure 3. A close look at three Freshwater Natural Reserves (FNR) in the headwaters of the Duero River tributaries (blue lines). The FNRs are fragmented and isolated from one another by numerous small dams and weirs (red dots). Vista de tres Reservas Naturales Fluviales (FNR) en la cabecera de ríos afluentes del río Duero (líneas azules). Las FNR están fragmentadas y aisladas unas de otras por numerosas pequeñas presas y azudes (puntos rojos).

2018) and fish community changes (Kanehl et al., 1997; Maloney et al., 2008; Poulos et al., 2014; Kornis et al., 2015). Conversely, some studies do not show significant positive changes (Kareiva et al., 2000; Stanley et al., 2007; Quiñones et al., 2014), while others point to short-term impacts in freshwater ecosystems (Stanley \& Doyle, 2003).

Exhaustive pre-removal studies are also essential as connectivity recovery may heighten the risk of exotic species invasion and disease dispersion in some rivers (Rahel, 2007; Stanley et al., 2007; Fausch et al., 2009; Zheng et al., 2009; Jackson \& Pringle, 2010).

In short, the results of connectivity restoration may depend on the type of river, dam, timescale and species involved. The new long-term ecosystem equilibrium may not be the same as that of the pre-dam ecosystem (Bellmore et al., 2019). General conclusions of connectivity restoration cannot yet be made as dam removal studies are scarce, short-term and focused on one or few components of the river ecosystem (Hart et al., 2002).
In the Iberian Peninsula, few dams and weirs have fish ladders and, moreover, fish ladders are usually inefficient or are not well evaluated (Nicola et al., 1996; Santos et al., 2006; Ordeix et al., 2011; Aparicio et al., 2012; Rincón Sanz \& Gortázar Rubial, 2016). To improve river connectivity in the last two decades, dam removal has become a more prominent restoration technique in Spain, and more than 150 weirs have been removed under the National Strategy for River Restoration (NSRR, MAGRAMA, 2015) and other different projects (LIFE Cipriber, 2015; LIFE Irekibai, 2016). However, there are usually no monitoring studies concerning the effects of the removal of these dams on fish communities, even though the NSRR includes monitoring as a part of each restoration project. In addition, the length of reconnected rivers is very short, so the ecological benefits of NSRR dam removal may be small in comparison to the costs (Rodeles et al., 2017). However, a cost-benefit analysis of 6 dam permeations was conducted to determine 
their effects in ecosystem services and suggest that permeations are beneficial to human well-being despite their costs (Rincón Sanz \& Gortázar Rubial, 2016).

Rivers have not received enough attention from governments in the Iberian Peninsula, but this situation is starting to change. The European Union established the Water Framework Directive (WFD), stating that good quality rivers must be achieved, and restoration of river connectivity is one of its aims. The WFD requires the consideration of fish communities when assessing the ecological quality of rivers (Council of the European Communities, 2000). Although Spain has not yet accomplished this objective and there is much work ahead, some large steps have been taken in this direction. While more organization and restoration monitoring are needed, the NSRR is a good starting point.

\section{FUTURE NEEDS}

Freshwater connectivity and conservation have gained attention in the last decades, as the profound impacts humans have on rivers are being acknowledged. However, the special characteristics of rivers (dendritic structure, directionality, etc.) make extrapolation from terrestrial ecosystems a poor method of study and conservation.

Thus, river connectivity conservation is a developing research field. The development of connectivity study methods has not been cohesive (Kemp \& O'Hanley, 2010), so the creation of general connectivity frameworks with the ability to adapt to more local circumstances would help spread river fragmentation assessments. Until now, only a few Iberian river basins have complete longitudinal connectivity assessments (Rincón Sanz \& Gortázar Rubial, 2016). The first step to achieve the evaluation of all river basins in the Iberian Peninsula and in the world is the development of an inventory of all obstacles (dams, weirs, culverts, etc.) found in streams. In Spain that inventory is incomplete so more effort is needed to improve it. Each barrier has to be located and its passability assessed (height, fisway presence, etc., Rincón Sanz \& Gortázar Rubial, 2016). With the complete barrier inventory river connectivity will be able to be assessed for all Iberian river basins.
These river connectivity assessments could then be used to detect the most impacting dams, vulnerable river stretches, critical fluvial paths and the best streams for conservation.

To ensure the creation of effective river management and conservation plans, connectivity assessments need to accurately represent reality. However, connectivity indices are typically theoretical models built with as little as three variables (dam passability, dam location and segment length, Kemp \& O'Hanley, 2010). Attempts at linking river basin connectivity models to population or community dynamics are almost non-existent due to the difficulty of finding large-scale ecological data (Perkin \& Gido, 2012). We need to validate existing connectivity indices with real world ecological data to ensure the benefits of river conservation and restoration actions.

Finally, river connectivity needs to be considered in the selection of river segments for conservation. Spanish FNRs are supposed to be well preserved areas. However, as showed in this review, there are many FNR divided in numerous isolated fragments due to weirs and dams. As stated before, there are different methods in the literature developed to include river connectivity in conservation reserves assessment and new ones could be developed to respond to specific needs.

None of these developed methods for river connectivity assessment are useful if they are not applied in river conservation. There needs to be a better communication between scientists and decision-makers to ensure adequate ecological methods are applied in river management and conservation (Rodeles et al., 2017). This way we would effectively preserve river ecosystem services and biodiversity in a changing and increasingly humanized world.

\section{ACKNOWLEDGEMENTS}

This research was performed thanks to the Ph.D. grants received from the Government of Navarra and the Asociación de Amigos de la Universidad de Navarra.

\section{REFERENCES}

ALEXANDRE, C.M. \& P. R. ALMEIDA. 2010. 
The impact of small physical obstacles on the structure of freshwater fish assemblages. River Research and Applications, 26: 977-994.

ALMODÓVAR, A. \& G. G. NICOLA. 1997. Effects of a small hydroelectric power station on brown trout (Salmo trutta L.) population in the Hoz Seca river (Tagus River, Spain). Regulated rivers: research and management, 484 (May 1998): 477-484.

Álvarez, J., Á. ANTÓN, J.M. ARAUJO, P. BRUFAO, P. CABALLERO, S. CONSUEGRA, B. ELVIRA, I. L. FERNÁNDEZ, J. DE LA FUENTE, A. GALERA, C. GARCÍA DE LEÁNIZ, M. GARCÍA REGO, F. HERVELLA, G. HOLDENSGAARD, J. DE LA HOZ, M. LAMUELA, C. F. Q. MAIA, Í. MENDIOLA, C. OTERO, C. RODRIGUEZ, A. RUÍZ, J. A. SÁNCHEZ, J. SCHNEIDER, Á. SERDIO, I. URRIZALKI, A. C. N. VALENTE, E. VERSPOOR, O. VIGFÚSSON, A. F. YOUNGSON \& F. J. ZATARAÍN. 2001. El salmón, joya de nuestros ríos. C. García de Leániz, A. Serdio, and C. Consuegra (eds.). Consejería de Ganadería, Agricultura y Pesca; Gobierno de Cantabria. Santander.

ÁLVAREZ, J., I. URRIZALKI, I. MENDIOLA, C. RODRÍGUEZ, S. CONSUEGRA, C. GARCÍA DE LEÁNIZ \& A. SERDIO. 2003. Densidad de obstáculos y su incidencia sobre el área utilizada por el Salmón atlántico en los ríos ibéricos. In: Un viaje de ida y vuelta. IV Jornadas del Salmón atlántico en la Península Ibérica. M. Lamuela and J. Álvarez (eds.): 177-186. Departamento de Medio Ambiente, Ordenación del Territorio y Vivienda; Gobierno de Navarra. Pamplona.

ANTUNES, C., F. COBO \& M. J. ARAÚJO. 2016. Iberian inland fishes. In: Freshwater fisheries ecology. J. F. Craig (ed.): 268-282. Wiley \& Sons. Singapore.

APARICIO, E., C. PINTOR, C. DURÁN \& G. CARMONA-CATOT. 2012. Fish passage assessment at the most downstream barrier of the Ebro River (NE Iberian Peninsula). Limnetica, 31 (1): 37-46.

APARICIO, E., M. J. VARGAS, J. M. OLMO \& A. DE SOSTOA. 2000. Decline of native freshwater fishes in a Mediterranean watershed on the Iberian Peninsula: a quantitative assessment. Environmental Biology of Fishes, 59: 11-19.

BAIN, M. B. \& M. L. WINE. 2010. Testing predictions of stream landscape theory for fish assemblages in highly fragmented watersheds. Folia Zoologica, 59 (3): 231-239.

BEDNAREK, A. T. 2001. Undamming rivers: a review of the ecological impacts of dam removal. Environmental Management, 27 (6): 803-814.

BELLMORE, J. R., G. R. PESS, J. J. DUDA, J. E. O'CONNOR, A. E. EAST, M. M. FOLEY, A. C. WILCOX, J. J. MAJOR, P. B. SHAFROTH, S. A. MORLEY, C. S. MAGIRL, C. W. ANDERSON, J. E. EVANS, C. E. TORGERSEN \& L. S. CRAIG. 2019. Conceptualizing ecological responses to dam removal: if you remove it, what's to come? BioScience, 69 (1): 26-39.

BENEJAM, L., S. SAURA-MAS, M. BARDINA, C. SOLÀ, A. MUNNÉ \& E. GARCÍA-BERTHOU. 2014. Ecological impacts of small hydropower plants on headwater stream fish: from individual to community effects. Ecology of Freshwater Fish, 25: 295-306.

BIRNIE-GAUVIN, K., M. M. CANDEE, H. BAKTOFT, M. H. LARSEN, A. KOED \& K. AARESTRUP. 2018. River connectivity reestablished: effects and implications of six weir removals on brown trout smolt migration. River Research and Applications, 34 (6): 548-554.

BOURNE, C. M., D. G. KEHLER, Y. F. WIERSMA \& D. COTE. 2011. Barriers to fish passage and barriers to fish passage assessments: the impact of assessment methods and assumptions on barrier identification and quantification of watershed connectivity. Aquatic Ecology, 45 (3): 389-403.

BOWER, S. D., R. J. LENNOX \& S. J. COOKE. 2015. Is there a role for freshwater protected areas in the conservation of migratory fish? Inland Waters, 5 (1): 1-6.

BRANCO, P., P. SEGURADO, J. M. SANTOS, P. PINHEIRO \& M. T. FERREIRA. 2012. Does longitudinal connectivity loss affect the distribution of freshwater fish? Ecological Engineering, 48: 70-78.

BRANCO, P., P. SEGURADO, J. M. SANTOS 
\& M. T. FERREIRA. 2014. Prioritizing barrier removal to improve functional connectivity of rivers. Journal of Applied Ecology, 51: 1197-1206.

BRANCO, P., S. D. AMARAL, M. T. FERREIRA \& J. M. SANTOS. 2017. Do small barriers affect the movement of freshwater fish by increasing residency? Science of the Total Environment, 581-582: 486-494.

BROWN, J. J., K. E. LIMBURG, J. R. WALDMAN, K. STEPHENSON, E. P. GLENN, F. JUANES \& A. JORDAAN. 2013. Fish and hydropower on the U.S. Atlantic coast: failed fisheries policies from half-way technologies. Conservation Letters, 6: 280-286.

BUNN, S. E. \& A. H. ARTHINGTON. 2002. Basic principles and ecological consequences of altered flow regimes for aquatic biodiversity. Environmental Management, 30 (4): 492-507.

CAMPBELL GRANT, E. H., W. H. LOWE \& W. F. FAGAN. 2007. Living in the branches: population dynamics and ecological processes in dendritic networks. Ecology Letters, 10 (2): $165-175$.

CARVAJAL-QUINTERO, J., F. VILLALOBOS, T. OBERDORFF, G. GRENOUILLET, S. BROSSE, B. HUGUENY, C. JÉZÉQUEL \& P. A. TEDESCO. 2019. Drainage network position and historical connectivity explain global patterns in freshwater fishes' range size. Proceedings of the National Academy of Sciences of the United States of America, 116 (27): 13434-13439.

CLAVERO, M., F. BLANCO-GARRIDO \& J. PRENDA. 2004. Fish fauna in Iberian Mediterranean river basins: biodiversity, introduced species and damming impacts. Aquatic Conservation: Marine and Freshwater Ecosystems, 14 (6): 575-585.

CLAVERO, M., V. HERMOSO, N. LEVIN \& S. KARK. 2010. Geographical linkages between threats and imperilment in freshwater fish in the Mediterranean Basin. Diversity and Distributions, 16 (5): 744-754.

CLAVERO, M. \& V. HERMOSO. 2011. Reservoirs promote the taxonomic homogenization of fish communities within river basins. Biodiversity and Conservation, 20 (1): 41-57.
CLAVERO, M. \& V. HERMOSO. 2015. Historical data to plan the recovery of the European eel. Journal of Applied Ecology, 52 (4): 960-968.

CONFEDERACIÓN HIDROGRÁFICA DEL DUERO. 2007. Visor DMA Duero. Available from: http://www.mirame.chduero.es/DMADuero 09 Viewer/viewerShow.do?action= showViewer (February 22, 2016).

CONFEDERACIÓN HIDROGRÁFICA DEL EBRO. 2009. SITEbro. Available from: http://iber.chebro.es/geoportal/ (February 8, 2019).

CORREA AYRAM, C. A., M. E. MENDOZA, A. ETTER \& D. R. P. SALICRUP. 2015. Habitat connectivity in biodiversity conservation: a review of recent studies and applications. Progress in Physical Geography, 40 (1): 7-37.

COTE, D., D. G. KEHLER, C. BOURNE \& Y. F. WIERSMA. 2009. A new measure of longitudinal connectivity for stream networks. Landscape Ecology, 24: 101-113.

COUNCIL OF THE EUROPEAN COMMUNITIES. 2000. Directive 2000/60/EC of the European Parliament and of the Council of 23 October 2000 establishing a framework for Community action in the field of water policy. Official Journal of the European Communities, 43: 1-73.

CROOK, D. A., W. H. LOWE, F. W. ALLENDORF, T. ERÖS, D. S. FINN, B. M. GILLANDERS, W. L. HADWEN, C. HARROD, V. HERMOSO, S. JENNINGS, R. W. KILADA, I. NAGELKERKEN, M. M. HANSEN, T. J. PAGE, C. RIGINOS, B. FRY \& J. M. HUGHES. 2015. Human effects on ecological connectivity in aquatic ecosystems: integrating scientific approaches to support management and mitigation. Science of The Total Environment, 534: 52-64.

CUMMING, G. S. 2004. The impact of low-head dams on fish species richness in Wisconsin, USA. Ecological Applications, 14 (5): 1495-1506.

DIEBEL, M. W., M. FEDORA, S. COGSWELL \& J. R. O'HANLEY. 2015. Effects of road crossings on habitat connectivity for stream-resident fish. River research and 
applications, 31: 1251-1261.

DODD, H. R., D. B. HAYES, J. R. BAYLIS, L. M. CARL, J. D. GOLDSTEIN, R. L. MCLAUGHLIN, D. L. G. NOAKES, L. M. PORTO \& M. L. JONES. 2003. Low-head sea lamprey barrier effects on stream habitat and fish communities in the Great Lakes basin. Journal of Great Lakes Research, 29: 386-402.

DOYLE, M. W., J. M. HARBOR \& E. H. STANLEY. 2003. Toward policies and decision-making for dam removal. Environmental Management, 31 (4): 453-465.

DOYLE, M., E. STANLEY, C. ORR, A. SELLE, S. SETHI \& J. HARBOR. 2005. Stream ecosystem response to small dam removal: lessons from the Heartland. Geomorphology, 71 (1-2): 227-244.

DUDGEON, D., A. H. ARTHINGTON, M. O. GESSNER, Z. -I. KAWABATA, D. J. KNOWLER, C. LÉVÊQUE, R. J. NAIMAN, A. -H. PRIEUR-RICHARD, D. SOTO, M. L. J. STIASSNY \& C. A SULLIVAN. 2006. Freshwater biodiversity: importance, threats, status and conservation challenges. Biological reviews of the Cambridge Philosophical Society, 81 (2): 163-182.

DUNCAN, J. R. \& J. L. LOCKWOOD. 2001. Extinction in a field of bullets: a search for causes in the decline of the world's freshwater fishes. Biological Conservation, 102 (1): 97-105.

ERÖS, T., D. SCHMERA \& R. S. SCHICK. 2011. Network thinking in riverscape conservation - a graph-based approach. Biological Conservation, 144 (1): 184-192.

ERÖS, T., J. R. O'HANLEY \& I. CZEGLÉDI. 2018. A unified model for optimizing riverscape conservation. Journal of Applied Ecology, 1871-1883.

EWERS, R. M. \& R. K. DIDHAM. 2006. Confounding factors in the detection of species responses to habitat fragmentation. Biological Reviews, 81: 117-142.

FAGAN, W. F. 2002. Connectivity, fragmentation, and extinction risk in dendritic metapopulations. Ecology, 83 (12): 3243-3249.

FAUSCH, K. D., C. E. TORGERSEN, C. V. BAXTER \& H. W. LI. 2002. Landscapes to riverscapes: bridging the gap between research and conservation of stream fishes. Bioscience, 52 (6): 483-498.

FAUSCH, K. D., B. E. RIEMAN, J. B. DUNHAM, M. K. YOUNG \& D. P. PETERSON. 2009. Invasion versus isolation: trade-offs in managing native salmonids with barriers to upstream movement. Conservation Biology, 23 (4): 859-870.

FJELDSTAD, H. -P., B. T. BARLAUP, M. STICKLER, S. -E. GABRIELSEN \& K. ALFREDSEN. 2012. Removal of weirs and the influence on physical habitat for salmonids in a norwegian river. River research and applications, 28: 753-763.

FUKUSHIMA, M., S. KAMEYAMA, M. KANEKO, K. NAKAO \& E. ASHLEY STEEL. 2007. Modelling the effects of dams on freshwater fish distributions in Hokkaido, Japan. Freshwater Biology, 52 (8): 1511-1524.

FUlLERTON, A. H., K. M. BURNETT, E. A. STEEL, R.L. FLITCROFT, G. R. PESS, B. E. FEIST, C. E. TORGERSEN, D. J. MILLER \& B. L. SANDERSON. 2010. Hydrological connectivity for riverine fish: measurement challenges and research opportunities. Freshwater Biology, 55 (11): 2215-2237.

FULLERTON, A. H., S. T. LINDLEY, G. R. PESS, B. E. FEIST, E. A. STEEL \& P. MCELHANY. 2011. Human influence on the spatial structure of threatened Pacific salmon metapopulations. Conservation Biology, 25 (5): 932-944.

GALPERN, P., M. MANSEAU \& A. FALL. 2011. Patch-based graphs of landscape connectivity: a guide to construction, analysis and application for conservation. Biological Conservation, 144 (1): 44-55.

GARCIA DE LEANIZ, C. 2008. Weir removal in salmonid streams: implications, challenges and practicalities. Hydrobiologia, 609 (1): 83-96.

GELDMANN, J., M. BARNES, L. COAD, I. D. CRAIGIE, M. HOCKINGS \& N. D. BURGESS. 2013. Effectiveness of terrestrial protected areas in reducing habitat loss and population declines. Biological Conservation, 161: 230-238. 
GIDO, K. B., J. E. WHITNET, J. S. PERKIN \& T. F. TURNER. 2016. Fragmentation, connectivity and fish species persistence in freshwater ecosystems. In: Conservation of Freshwater Fishes. G. P. Closs, M. Krkosek, and J. D. Olden (eds.): 293-323. Cambridge University Press. Cambridge.

GREGORY, S., H. LI \& J. LI. 2002. The conceptual basis for ecological responses to dam removal. BioScience, 52 (8): 713-723.

GRILL, G., C. OUELlET DALLAIRE, E. FLUET CHOUINARD, N. SINDORF \& B. LEHNER. 2014. Development of new indicators to evaluate river fragmentation and flow regulation at large scales: a case study for the Mekong River basin. Ecological Indicators, 45: 148-159.

GRILL, G., B. LEHNER, A. E. LUMSDON, G. K. MACDONALD, C. ZARFL \& C. REIDY LIERMANN. 2015. An index-based framework for assessing patterns and trends in river fragmentation and flow regulation by global dams at multiple scales. Environmental Research Letters, 10 (1): 015001.

HANSKI, I. \& M. GILPIN. 1991. Metapopulation dinamics: brief history and conceptual domain. Biological Journal of the Linnean Society, 42: 3-16.

HART, D. D., T. E. JOHNSON, K. L. BUSHAW-NEWTON, R. J. HORWITZ, A. T. BEDNAREK, D. F. CHARLES, D. A. KREEGER \& D. J. VELINSKY. 2002. Dam removal: challenges and opportunities for ecological research and river restoration. BioScience, 52: 669-681.

HEINO, J., A. S. MELO, T. SIQUEIRA, J. SOININEN, S. VALANKO \& L. M. BINI. 2015. Metacommunity organisation, spatial extent and dispersal in aquatic systems: patterns, processes and prospects. Freshwater Biology, 60 (5): 845-869.

HERMOSO, V. \& M. CLAVERO. 2011. Threatening processes and conservation management of endemic freshwater fish in the Mediterranean basin: a review. Marine and Freshwater Research, 62: 244-254.

HERMOSO, V., S. LINKE, J. PRENDA \& H. P. POSSINGHAM. 2011. Addressing longitudinal connectivity in the systematic conserva- tion planning of fresh waters. Freshwater Biology, 56 (1): 57-70.

HERMOSO, V., M. J. KENNARD \& S. LINKE. 2012. Integrating multidirectional connectivity requirements in systematic conservation planning for freshwater systems. Diversity and Distributions, 18 (5): 448-458.

HERMOSO, V., A. F. FILIPE, P. SEGURADO \& P. R. BEJA. 2015. Effectiveness of a large reserve network in protecting freshwater biodiversity: a test for the Iberian Peninsula. Freshwater Biology, 60 (698-710).

HERMOSO, V., A. F. FILIPE, P. SEGURADO \& P. BEJA. 2017. Freshwater conservation in a fragmented world: dealing with barriers in a systematic planning framework. Aquatic Conservation: Marine and Freshwater Ecosystems, 28 (1): 17-25.

HITT, N.P., S. EYLER \& J. E. B. WOFFORD. 2012. Dam removal increases American eel abundance in distant headwater streams. Transactions of the American Fisheries Society, 141 (5): 1171-1179.

JACKSON, C. R. \& C. M. PRINGLE. 2010. Ecological benefits of reduced hydrologic connectivity in intensively developed landscapes. BioScience, 60 (1): 37-46.

KANEHL, P. D., J. LYONS \& J. E. NELSON. 1997. Changes in the habitat and fish community of the Milwaukee River, Wisconsin, following removal of the Woolen Mills dam. North American Journal of Fisheries Management, 17 (2): 387-400.

KAREIVA, P., M. MARVIER \& M. MCCLURE. 2000. Recovery and management options for spring / summer Chinook salmon in the Columbia River basin. Science, 290 (November): 977-979.

KEEFER, M. L., G. A. TAYLOR, D. F. GARLETTS, C. K. HELMS, G. A. GAUTHIER, T. M. PIERCE \& C. C. CAUDILL. 2012. Reservoir entrapment and dam passage mortality of juvenile Chinook salmon in the Middle Fork Willamette River. Ecology of Freshwater Fish, 21 (2): 222-234.

KEMP, P. S. \& J. R. O'HANLEY. 2010. Procedures for evaluating and prioritising the removal of fish passage barriers: a synthesis. Fisheries Management and Ecology, 17 (4): 
297-322.

KEMP, P. S. 2016. Impoundments, barriers and abstractions: impact on fishes and fisheries, mitigation and future directions. In: Freshwater fisheries ecology. J. F. Craig (ed.): 717-769. John Wiley \& Sons.

KING, S., J. R. O'HANLEY, L. R. NEWBOLD, P. S. KEMP \& M. W. DIEBEL. 2017. A toolkit for optimizing fish passage barrier mitigation actions. Journal of Applied Ecology, 54 (2): 599-611.

KING, S. \& J. R. O'HANLEY. 2016. Optimal fish passage barrier removal - revisited. River research and applications, 32: 418-428.

KONDOLF, G. M., Z. K. RUBIN \& J. T. MINEAR. 2014. Dams on the Mekong: cumulative sediment starvation. Water Resources Research, 50 (6): 5158-5169.

KORNIS, M. S., B. C. WEIDEL, S. M. POWERS, M. W. DIEBEL, T. J. CLINE, J. M. FOX \& J. F. KITCHELL. 2015. Fish community dynamics following dam removal in a fragmented agricultural stream. Aquatic Sciences, 77 (3): 465-480.

LASNE, E., M. R. SABATIÉ, N. JEANNOT \& J. CUCHEROUSSET. 2015. The effects of dam removal on river colonization by Sea lamprey Petromyzon marinus. River research and applications, 31: 904-911.

LEVINS, R. 1968. Some demographic and genetic consequences of environmental heterogeneity for biological control. Bulletin of the Entomological Society of America, 15: 237-240.

LIERMANN, C. R., C. NILSSON, J. ROBERTSON \& R. Y. NG. 2012. Implications of dam obstruction for global freshwater fish diversity. BioScience, 62 (6): 539-548.

LIFE CIPRIBER. 2015. Cipriber. Available from: https://cipriber.eu/ (February 8, 2018).

LIFE IREKIBAI. 2016. Irekibai. Available from: http://www.irekibai.eu/en/ (September 18, 2016).

LIMBURG, K. E. \& J. R. WALDMAN. 2009. Dramatic declines in North Atlantic diadromous fishes. BioScience, 59 (11): 955-965.

VAN LOOY, K., C. CAVILLON, T. TORMOS, J. PIFFADY, P. LANDRY \& Y. SOUCHON. 2013. A scale-sensitive connectivity analysis to identify ecological networks and conservation value in river networks. Landscape Ecology, 28 (7): 1239-1249.

LUCAS, M. C. \& E. BATLEY. 1996. Seasonal movements and behaviour of adult barbel Barbus barbus, a riverine cyprinid fish: implications for river management. Journal of Applied Ecology, 33: 1345-1358.

LUCAS, M. C., D. H. BUBB, M. H. JANG, K. HA \& J. E. G. MASTERS. 2009. Availability of and access to critical habitats in regulated rivers: effects of low-head barriers on threatened lampreys. Freshwater Biology, 54 (3): 621-634.

MACARTHUR, R. H. \& E. O. WILSON. 1967. The theory of island biogeography. Princeton University Press. Princeton, USA.

MACEDA-VEIGA, A. 2013. Towards the conservation of freshwater fish: Iberian Rivers as an example of threats and management practices. Reviews in Fish Biology and Fisheries, 23 (1): 1-22.

MAGRAMA. 2015. Estrategia Nacional de Restauración de Ríos. Available from: http://www.magrama.gob.es/es/agua/temas/ delimitacion-y-restauracion-del-dominiopublico-hidraulico/estrategia-nacionalrestauracion-rios/default.aspx (February 12, 2015).

MAITLAND, B. M., M. POESCH \& A. E. ANDERSON. 2016. Prioritising culvert removals to restore habitat for at-risk salmonids in the boreal forest. Fisheries Management and Ecology, 23 (6): 489-502.

MALONEY, K. O., H. R. DODD, S. E. BUTLER \& D. H. WAHL. 2008. Changes in macroinvertebrate and fish assemblages in a medium-sized river following a breach of a low-head dam. Freshwater Biology, 53 (5): 1055-1068.

MARCH, J. G., J. P. BENSTEAD, C. M. PRINGLE \& F. N. SCATENA. 2003. Damming tropical island streams: problems, solutions, and alternatives. BioScience, 53 (11): 1069.

DI MARCO, M., S. CHAPMAN, G. ALTHOR, S. KEARNEY, C. BESANCON, N. BUTT, J. M. MAINA, H. P. POSSINGHAM, K. ROGALLA VON BIEBERSTEIN, O. VENTER \& J. E. M. WATSON. 2017. Chan- 
ging trends and persisting biases in three decades of conservation science. Global Ecology and Conservation, 10: 32-42.

MCKAY, S. K., J. R. SCHRAMSKI, J. N. CONYNGHAM \& J. C. FISCHENICH. 2013. Assessing upstream fish passage connectivity with network analysis. Ecological Applications, 23 (6): 1396-1409

MCKAY, S. K., A. R. COOPER, M. W. DIEBEL, D. ELKINS, G. OLDFORD, C. ROGHAIR \& D. WIEFERICH. 2017. Informing watershed connectivity barrier prioritization decisions: a synthesis. River research and Applications, 33 (6): 847-862.

MELDGAARD, T., E. E. NIELSEN \& V. LOESCHCKE. 2003. Fragmentation by weirs in a riverine system: a study of genetic variation in time and space among populations of European grayling (Thymallus thymallus) in a Danish river system. Conservation Genetics, 4 (Vriejenhoek 1994): 735-747.

MINISTERIO PARA LA TRANSICIÓN ECOLÓGICA. 2017. Catálogo Nacional de Reservas Hidrológicas. Available from: https://www.miteco.gob.es/es/agua/temas/ delimitacion-y-restauracion-del-dominiopublico-hidraulico/Catalogo-Nacional-deReservas-Hidrologicas/normativa/ (February 18, 2019).

MIRANDA, R., J. MARTÍNEZ-LAGE, J. MOLINA, J. OSCOZ, I. TOBES \& A. VILCHES. 2012. Effects of stress controlled loading of a reservoir on downstream fish populations in a Pyrenean river. Environmental Engineering and Management Journal, 11 (6): 1125-1131.

MIRANDA, R. \& A. PINO-DEL-CARPIO. 2016. Analysing freshwater fish biodiversity records and respective conservation areas in Spain. Journal of Applied Ichthyology, 32 (1): 240-248.

MOILANEN, A., J. LEATHWICK \& J. ELITH. 2008. A method for spatial freshwater conservation prioritization. Freshwater Biology, 53 (3): 577-592.

MORAIS, P. 2008. Review on the major ecosystem impacts caused by damming and watershed development in an Iberian basin (SW-Europe): focus on the Guadiana estuary. Annales de Limnologie - International Journal of Limnology, 44 (2): 105-117.

MORITA, K. \& S. YAMAMOTO. 2002. Effects of habitat fragmentation by damming on the persistence of stream-dwelling Charr populations. Conservation Biology, 16 (5): 1318-1323.

MORITA, K., S. H. MORITA \& S. YAMAMOTO. 2009. Effects of habitat fragmentation by damming on salmonid fishes: lessons from white-spotted charr in Japan. Ecological Research, 24 (4): 711-722.

MOSS, B. 2000. Biodiversity in fresh waters an issue of species preservation or system functioning? Environmental Conservation, 27 (1): 1-4.

NICOLA, G., B. ELVIRA \& A. ALMODÓVAR. 1996. Dams and fish passage facilities in the large rivers of spain: effect on migratory species. Archiv fur hydrobiologie, 113 (1-4): 375-379.

NIELAND, J. L., T. F. SHEEHAN \& R. SAUNDERS. 2015. Assessing demographic effects of dams on diadromous fish: a case study for Atlantic salmon in the Penobscot River, Maine. ICES Journal of Marine Science, 72 (8): 2423-2437.

NISLOW, K. H., M. HUDY, B. H. LETCHER \& E. P. SMITH. 2011. Variation in local abundance and species richness of stream fishes in relation to dispersal barriers: implications for management and conservation. Freshwater Biology, 56 (10): 2135-2144.

NULL, S. E., J. MEDELLÍN-AZUARA, A. ESCRIVA-BOU, M. LENT \& J. R. LUND. 2014. Optimizing the dammed: water supply losses and fish habitat gains from dam removal in California. Journal of Environmental Management, 136: 121-131.

O'HANLEY, J. R. \& D. TOMBERLIN. 2005. Optimizing the removal of small fish passage barriers. Environmental Modeling and Assessment, 10 (2): 85-98.

O'HANLEY, J. R. 2011. Open rivers: barrier removal planning and the restoration of free-flowing rivers. Journal of Environmental Management, 92 (12): 3112-3120.

O'HANLEY, J. R., J. WRIGHT, M. DIEBEL, M. A. FEDORA \& C. L. SOUCY. 2013. Resto- 
ring stream habitat connectivity: a proposed method for prioritizing the removal of resident fish passage barriers. Journal of Environmental Management, 125 (April): 19-27.

ORDEIX, M., Q. POU-ROVIRA, N. SELLARÈS, M. BARDINA, A. CASAMITJANA, C. SOLÀ \& A. MUNNÉ. 2011. Fish pass assessment in the rivers of Catalonia (NE Iberian Peninsula). A case study of weirs associated with hydropower plants and gauging stations. Limnetica, 30 (2): 405-426.

OVIDIO, M. \& J. C. PHILIPPART .2002. The impact of small physical obstacles on upstream movements of six species of fish: Synthesis of a 5-year telemetry study in the River Meuse basin. Hydrobiologia, 483: 55-69.

PASCUAL-HORTAL, L. \& S. SAURA. 2006. Comparison and development of new graph-based landscape connectivity indices: towards the priorization of habitat patches and corridors for conservation. Landscape Ecology, 21 (7): 959-967.

PERKIN, J. S. \& K. B. GIDO. 2012. Fragmentation alters stream fish community structure in dendritic ecological networks. Ecological Applications, 22 (8): 2176-2187.

PESS, G. R., T. P. QUINN, S. R. GEPHARD \& R. SAUNDERS. 2014. Re-colonization of Atlantic and Pacific rivers by anadromous fishes: linkages between life history and the benefits of barrier removal. Reviews in Fish Biology and Fisheries, 24 (3): 881-900.

POULOS, H., K. MILLER, M. KRACZKOWSKI, A. WELCHEL, R. HEINEMANN \& B. CHERNOFF. 2014. Fish assemblage response to a small dam removal in the Eightmile River system, Connecticut, USA. Environmental Management, 54: 1090-1101.

PRENDA, J., M. CLAVERO, A. MENOR, V. HERMOSO \& E. CARMEN. 2006. Threats to the conservation of biotic integrity in Iberian fluvial ecosystems. Limnetica, 25: 377-388.

PRINGLE, C. 2003. What is hydrologic connectivity and why is it ecologically important? Hydrological Processes, 17 (13): 2685-2689.

PRINGLE, C. M. 2001. Hydrologic connectivity and the management of biological reserves : a global perspective. Ecological Applications,
11 (4): 981-998.

QUIÑONES, R. M., T. E. GRANTHAM, B. N. HARVEY, J. D. KIERNAN, M. KLASSON, A. P. WINTZER \& P. B. MOYLE. 2014. Dam removal and anadromous salmonid (Oncorhynchus spp.) conservation in California. Reviews in Fish Biology and Fisheries, 25: 195-215.

RAHEL, F. J. 2007. Biogeographic barriers, connectivity and homogenization of freshwater faunas: it's a small world after all. Freshwater Biology, 52 (4): 696-710.

REYJOL, Y., B. HUGUENY, D. PONT, P.G. BIANCO, U. BEIER, N. CAIOLA, F. CASALS, I. COWX, A. ECONOMOU, T. FERREIRA, G. HAIDVOGL, R. NOBLE, A. DE SOSTOA, T. VIGNERON \& T. VIRBICKAS. 2007. Patterns in species richness and endemism of European freshwater fish. Global Ecology and Biogeography, 16: 65-75.

RINCÓN, G., J. SOLANA-GUTIÉRREZ, C. ALONSO, S. SAURA \& D. GARCÍA DE JALÓN. 2017. Longitudinal connectivity loss in a riverine network: accounting for the likelihood of upstream and downstream movement across dams. Aquatic Sciences, 79 (3): 573-585.

RINCÓN SANZ, G. \& J. GORTÁZAR RUBIAL. 2016. An analysis of river fragmentation in the Spanish river basins. $112 \mathrm{pp}$

RODELES, A. A., D. GALICIA \& R. MIRANDA. 2017. Recommendations for monitoring freshwater fishes in river restoration plans: a wasted opportunity for assessing impact. Aquatic Conservation: Marine and Freshwater Ecosystems, 27 (4): 880-885.

RODELES, A. A., P. M. LEUNDA, J. ELSO, J. ARDAIZ, D. GALICIA \& R. MIRANDA. 2019. Consideration of habitat quality in a river connectivity index for anadromous fishes. Inland Waters, : 1-11.

SÁ-OLIVEIRA, J. C., J. E. HAWES, V. J. ISAAC-NAHUM \& C. A. PERES. 2015. Upstream and downstream responses of fish assemblages to an Eastern Amazonian hydroelectric dam. Freshwater Biology, 60: 2037-2050.

SANTOS, J. M., M. T. FERREIRA, A. N. PINHEIRO \& J. H. BOCHECHAS. 2006. 
Effects of small hydropower plants on fish assemblages in medium-sized streams in central and northern Portugal. Aquatic Conservation: Marine and Freshwater Ecosystems, 16 (4): 373-388.

SANZ AZCÁRATE, L., C. PÉREZ MARTÍN, M. N. VIZCAY URRUTIA, J. ARDAIZ GANUZA \& A. VARELA ÁLVAREZ. 2018. Revirtiendo la fragmentación en la cuenca del Bidasoa. El proyecto LIFE IREKIBAI en Navarra. In: Retos y experiencias de restauración fluvial en el ámbito de la Red Natura 2000. J. R. Díez and A. Ibisate (eds.): 250-267. Gobierno Vasco. Vitoria-Gasteiz (Spain).

SAUNDERS, D. L., J. J. MEEUWIG \& A. C. J. VINCENT. 2002. Freshwater protected areas: strategies for conservation. Conservation Biology, 16 (1): 30-41.

SCHEWE, J., J. HEINKE, D. GERTEN, I. HADDELAND, N. W. ARNELL, D. B. CLARK, R. DANKERS, S. EISNER, B. M. FEKETE, F. J. COLÓN-GONZÁLEZ, S. N. GOSLING, H. KIM, X. LIU, Y. MASAKI, F. T. PORTMANN, Y. SATOH, T. STACKE, Q. TANG, Y. WADA, D. WISSER, T. ALBRECHT, K. FRIELER, F. PIONTEK, L. WARSZAWSKI \& P. KABAT. 2014. Multimodel assessment of water scarcity under climate change. Proceedings of the National Academy of Sciences, 111 (9): 3245-3250.

SCHMUTZ, S. \& O. MOOG. 2018. Dams: ecological impacts and management. In: Riverine ecosystem management. Science for governing towards a sustainable future. S. Schmutz and J. Sendzimir (eds.): 111-127. Amsterdam.

SEGURADO, P., P. BRANCO \& M. T. FERREIRA. 2013. Prioritizing restoration of structural connectivity in rivers: a graph based approach. Landscape Ecology, 28 (7): 1231-1238

SEGURADO, P., P. BRANCO, A. P. AVELAR \& M. T. FERREIRA. 2015. Historical changes in the functional connectivity of rivers based on spatial network analysis and the past occurrences of diadromous species in Portugal. Aquatic Sciences, 77 (3): 427-440.

SELIGER, C. \& B. ZEIRINGER. 2018. River Connectivity, habitat fragmentation and related restoration measures. In: Riverine ecosystem management. Science for governing towards a sustainable future. S. Schmutz and J. Sendzimir (eds.): 171-186. Springer. Amsterdam.

SHEER, M. B. \& E. A. STEEL. 2006. Lost watersheds: barriers, aquatic habitat connectivity, and salmon persistence in the Willamette and lower Columbia River basins. Transactions of the American Fisheries Society, 135 (6): 1654-1669.

SMITH, K. G. \& W. R. T. DARWALL. 2006. Assessment The status and distribution of freshwater fish endemic to the Mediterranean basin, 1: IUCN. Gland, Switzerland and Cambridge, UK.

SOLÀ, C., M. ORDEIX, Q. POU-ROVIRA, N. SELLARÈS, A. QUERALT, M. BARDINA, A. CASAMITJANA \& A. MUNNÉ. 2011. Longitudinal connectivity in hydromorphological quality assessments of rivers. The ICF index: a river connectivity index and its application to Catalan rivers. Limnetica, 30 (2): 273-292.

STANLEY, E. H., M. J. CATALANO, N. MERCADO-SILVA \& C. H. ORR. 2007. Effects of dam removal on brook trout in a Wisconsin stream. River Research and Applications, 23: 792-798.

STANLEY, E. H. \& M. W. DOYLE. 2003. Trading off: the ecological effects of dam removal. Frontiers in Ecology and the Environment, 1 (1): 15-22.

TAYLOR, P. D., L. FAHRIG, K. HENEIN \& G. MERRIAM. 1993. Connectivity is a vital element of landscape structure. Oikos, 68 (3): 571-573.

TISCHENDORF, L. \& L. FAHRIG. 2000. On the usage and measurement of landscape connectivity. Oikos, 90 (1): 7-19.

VALENTE, A. C. N. \& C. F. Q. MAIA. 2001. Situación actual del salmón atlántico en Portugal. In: El salmón, joya de nuestros ríos. C. García de Leániz, A. Serdio, and S. Consuegra (eds.): 17-25. Consejería de Ganadería, Agricultura y Pesca; Gobierno de Cantabria. Santander.

VIDAL-ABARCA GUTIÉRREZ, M. R. \& M. L. SUÁREZ ALONSO. 2013. Which are, what is their status and what can we expect from 
ecosystem services provided by Spanish rivers and riparian areas? Biodiversity and Conservation, 22 (11): 2469-2503.

WANG, L., D. INFANTE, J. LYONS, J. STEWART \& A. COOPER. 2011. Effects of dams in river networks on fish assemblages in non-impoundment sections of rivers in Michigan and Wisconsin, USA. River research and applications, 27: 473-487.

WIENS, J. A. 2002. Riverine landscapes : taking landscape ecology into the water. Freshwater Biology, 47: 501-515.

WOFFORD, J. E. B., R. E. GRESSWELL \& M. A. BANKS. 2005. Influence of barriers to movement on within-watershed genetic variation of coastal cutthroat trout. Ecological Applications, 15 (2): 628-637.

YAMAMOTO, S., K. MORITA, I. KOIZUMI \& K. MAEKAWA. 2004. Genetic differentiation of white-spotted charr (Salvelinus leucomaenis) populations after habitat fragmentation: spatial-temporal changes in gene frequencies. Conservation Genetics, 5 (4): 529-538.

ZHENG, P. Q., B. F. HOBBS \& J. F. KOONCE. 2009. Optimizing multiple dam removals under multiple objectives: linking tributary habitat and the Lake Erie ecosystem. Water Resources Research, 45 (12): 1-14.

Con el patrocinio de:

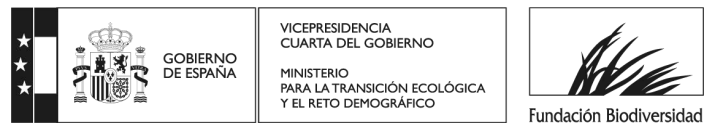

